\title{
Liver transplantation for hepatic cirrhosis in cystic fibrosis
}

\author{
G Noble-Jamieson, J Valente, N D Barnes, P J Friend, N V Jamieson, A Rasmussen, \\ R Y Calne
}

\begin{abstract}
Five children with cystic fibrosis complicated by hepatic cirrhosis received liver grafts. They all had portal hypertension with varices and three had variceal bleeding; respiratory function was only moderately impaired, but four were colonised with pseudomonas and one with aspergillus. Liver transplantation was well tolerated and there was no increase in respiratory or other early postoperative complications. Four of the children were fully well from 14 to 35 months after transplantation; the most recently transplanted had problems from a biliary stricture. In spite of the need for immunosuppression there was no increase in infection and respiratory function improved or remained stable. Once the children were stabilised after transplantation their nutrition and general health were greatly improved.

(Arch Dis Child 1994; 71: 349-352)
\end{abstract}

In patients with cystic fibrosis improved management of the lung problems has increased life expectancy and more patients now develop extrapulmonary complications. ${ }^{1}$ Hepatic cirrhosis occurs in up to $25 \%$ of children with cystic fibrosis and may progress to severe portal hypertension. ${ }^{2}$ This problem usually presents within the first 10 years of life with hepatosplenomegaly, but only mild derangement of liver function. Once portal hypertension is established the prognosis is poor; in one series $20 \%$ of affected children died as a direct result of the liver disease, with a mean survival of only 4.5 years, ${ }^{3}$ and in this and other series an excess of respiratory deaths has been noted in children with liver disease. ${ }^{2}$ Although portal systemic shunting may be palliative, liver transplantation offers the only potentially curative treatment for portal hypertension. It has seldom been attempted for several reasons, however; firstly, it is difficult to

Table 1 Clinical details of patients at assessment for transplantation

\begin{tabular}{|c|c|c|c|c|c|c|}
\hline $\begin{array}{l}\text { Patient } \\
\text { No }\end{array}$ & Sex & $\begin{array}{l}\text { Age } \\
\text { (years) }\end{array}$ & Diagnosis & Varices & Bleeding & Other problems \\
\hline $\begin{array}{l}1 \\
2\end{array}$ & $\begin{array}{l}\mathrm{F} \\
\mathrm{M}\end{array}$ & $\begin{array}{l}14 \cdot 4 \\
11 \cdot 8\end{array}$ & $\begin{array}{l}\mathrm{CF} \\
\mathrm{CF}\end{array}$ & $\begin{array}{l}+ \\
+\end{array}$ & $\begin{array}{l}++ \\
-\end{array}$ & Malnutrition \\
\hline 3 & M & $14 \cdot 2$ & $\mathrm{CF}$ & + & ++ & Malnutrition \\
\hline 4 & $\mathrm{~F}$ & $6 \cdot 6$ & $\mathrm{CF}$ & + & - & $\begin{array}{l}\text { Malnutrition; previous ileostomy for } \\
\text { meconium ileus; diabetes mellitus }\end{array}$ \\
\hline 5 & $\mathbf{M}$ & $5 \cdot 8$ & $\begin{array}{l}\text { CF } \\
\text { AlATD }\end{array}$ & + & + & $\begin{array}{l}\text { Malnutrition and ascites; previous } \\
\text { ileostomy and resection for } \\
\text { meconium ileus, colonic ulceration; } \\
\text { septic episodes }\end{array}$ \\
\hline
\end{tabular}

$\mathrm{CF}=$ cystic fibrosis; A1 ATD $=\alpha_{1}$-antitrypsin deficiency. judge the optimum timing of the procedure; secondly, the lung problems may increase the immediate risk of the operation; and, thirdly, it was feared that, without simultaneous lung transplantation, postoperative pulmonary infection might progress rapidly on immunosuppression.

We now report the encouraging outcome of liver transplantation in five children with cystic fibrosis and hepatic cirrhosis.

\section{Patients}

Five children with cystic fibrosis, three boys and two girls aged from 5 to 14 years, received liver grafts at Addenbrooke's Hospital between March 1991 and June 1993. Table 1 gives their clinical details at assessment. In addition to cystic fibrosis, patient 5 was found to have $\alpha_{1}$-antitrypsin deficiency; a preoperative liver biopsy sample showed the histological changes of the two disorders. In the neonatal period patients 4 and 5 had ileostomies for meconium ileus: patient 5 also required resection of $30-50 \%$ of the small bowel; he later had a further operation for intestinal obstruction and developed colonic ulceration.

In these children liver disease was first detected from 2 to 12 years of age. Patients 2 and 3 were found to have hepatosplenomegaly, patients 1 and 5 an increase in liver enzymes, and patient 4 deranged clotting. At the time of assessment for liver transplantation all the children had portal hypertension with gross splenomegaly and large varices shown on endoscopy or ultrasound. Patients 3 and 5 had recurrent major variceal bleeds despite sclerotherapy. Patient 5 had had gastrointestinal bleeding sufficiently severe to require transfusion. None of the children were jaundiced (bilirubin concentrations 7-25 $\mu \mathrm{mol} / \mathrm{l}$ ), but their liver enzymes were slightly increased with alanine transaminase 40-105 $\mathrm{mmol} / \mathrm{l}$ and alkaline phosphatase 158-604 $\mathrm{mmol} / \mathrm{h}$, and three had prolonged prothrombin times of 20-21 seconds. Indices of hypersplenism were present in all the children, with total white cell counts ranging from 1.8 to $5.2 \times 10^{9} / 1$ and platelet counts from 57 to $88 \times 10^{9} / 1$. Nutritional status as judged by triceps skinfold thickness and upper arm circumference was poor (less than the fifth centiles) in four children (table 2).

All the children had copious sputum production and breathlessness on exertion. Respiratory function was measured in the four older children and was mildly to moderately impaired (table 3). Three were colonised with Pseudomonas aeruginosa, one with 
Table 2 Nutritional indicators (centiles for triceps skinfold and upper arm circumference ${ }^{14} 15$ ) before transplantation and latest recorded values

\begin{tabular}{|c|c|c|c|c|c|c|}
\hline \multirow[b]{2}{*}{$\begin{array}{l}\text { Patient } \\
\text { No }\end{array}$} & \multicolumn{3}{|c|}{ Triceps skinfold (\%) } & \multicolumn{3}{|c|}{ Upper arm circumference (\%) } \\
\hline & $\begin{array}{l}\text { Before } \\
\text { transplantation }\end{array}$ & $\begin{array}{l}\text { Latest } \\
\text { measurement }\end{array}$ & $\begin{array}{l}\text { Months after } \\
\text { transplantation }\end{array}$ & $\begin{array}{l}\text { Before } \\
\text { transplantation }\end{array}$ & $\begin{array}{l}\text { Latest } \\
\text { measurement }\end{array}$ & $\begin{array}{l}\text { Months after } \\
\text { transplantation }\end{array}$ \\
\hline $\begin{array}{l}1 \\
2 \\
3 \\
4 \\
5\end{array}$ & $\begin{array}{r}<3 \\
20 \\
30 \\
<3 \\
8\end{array}$ & $\begin{array}{r}6 \\
>97 \\
80 \\
30 \\
8\end{array}$ & $\begin{array}{r}27 \\
10 \\
15 \\
12 \\
7\end{array}$ & $\begin{array}{r}<5 \\
10 \\
<5 \\
5 \\
<5\end{array}$ & $\begin{array}{l}<5 \\
80 \\
20 \\
20 \\
<5\end{array}$ & $\begin{array}{r}27 \\
10 \\
15 \\
12 \\
7\end{array}$ \\
\hline
\end{tabular}

pseudomonas and aspergillus, and one with haemophilus and Streptococcus pneumoniae. Patient 4 had diabetes mellitus of recent onset and required insulin in a dose of one unit/kg/day.

In the three children who had not had major variceal bleeds the decision to proceed to transplantation was difficult. After full discussion with the parents, in view of the children's deteriorating quality of life, poor nutritional status, abdominal distension with diaphragmatic splinting from organomegaly or ascites, or both, pancytopenia from hypersplenism, and large varices, and against the background of the encouraging results previously reported and in our own first two patients, we felt that the potential benefit outweighed the risks and that their lung function was too well preserved to merit the additional risks and problems of double transplantation with liver and lung, or triple with liver, heart, and lung.

\section{Transplantation and postoperative progress}

After a waiting time of one to three months the children received whole orthotopic liver grafts matched for size and blood group. The operative procedure was straightforward in three, but the two children who had had a previous abdominal operation presented more technical problems and had increased intraoperative blood loss (mean $158 \mathrm{ml} / \mathrm{kg}$ compared with 39 $\mathrm{ml} / \mathrm{kg}$ in those who had no previous operation). Patient 4 required a splenectomy to make enough room in the abdomen for the graft. Postoperatively the children were given quadruple immunosuppression according to our then current protocol (prednisolone and azathioprine from day 1 , antithymoglobulin from day 2 for five days, and cyclosporin starting from day 2) and for five days were treated prophylactically with antibiotics appropriate for their flora. The children with positive aspergillus cultures or serology were also given prophylactic antifungal drugs.

All the children made good progress in the early postoperative period. The mean stay in intensive care was five days (range three to eight days) and the duration of mechanical ventilation was short (from less than one to three days). Pulmonary infection did not cause any major problems, although two children required a change in antibiotic treatment. The only other complication related to the cystic fibrosis was meconium ileus equivalent in patient 1 ; obstruction was successfully relieved with Gastrografin enemas and acetylcysteine by mouth. The children were discharged home after a mean stay in hospital of only three weeks (range 12-38 days). Hepatic complications occurred later in two children. Patient 4 developed an anastomotic biliary stricture at six weeks; this was successfully treated by percutaneous transhepatic dilatation; she then had cytomegalovirus reactivation hepatitis which responded to a two week course of ganciclovir. Patient 5 developed biliary obstruction three weeks postoperatively and required reconstruction of the biliary tract to convert a duct to duct anastomosis to a Roux loop. He subsequently had an episode of acute rejection and at seven months had not recovered normal liver function, although a liver biopsy sample did not show evidence of irreversible damage.

In spite of the pancreatic enzyme supplements they were receiving, to maintain therapeutic concentrations of cyclosporin all the children required high total doses (10-35 $\mathrm{mg} / \mathrm{kg} /$ day) given in three doses daily. Even so, in patient 5 it proved impossible to maintain adequate concentrations of cyclosporin so he was changed to the better absorbed immunosuppressant FK506 (Fujisawa, Munich, Germany).

Among the four children with normal graft function nutrition was greatly improved (table 2 ) in three. Patient 1 unfortunately became anorexic, but started to gain weight after the insertion of a gastrostomy feeding tube. A surprising and gratifying outcome was a striking subjective improvement in respiratory function in all the children; they showed remarkably improved exercise tolerance and decreased cough and sputum production.

Table 3 Indicators of respiratory function (forced vital capacity (FVC) and forced expiratory volume in one second $\left(F E V_{1}\right)$, \% predicted) before transplantation and latest recorded value

\begin{tabular}{|c|c|c|c|c|c|c|}
\hline \multirow[b]{2}{*}{$\begin{array}{l}\text { Patient } \\
\text { No }\end{array}$} & \multicolumn{3}{|l|}{$F E V_{1}$} & \multicolumn{3}{|l|}{$F V C$} \\
\hline & $\begin{array}{l}\text { Before } \\
\text { transplantation }\end{array}$ & $\begin{array}{l}\text { Latest } \\
\text { measurement }\end{array}$ & $\begin{array}{l}\text { Months after } \\
\text { transplantation }\end{array}$ & $\begin{array}{l}\text { Before } \\
\text { transplantation }\end{array}$ & $\begin{array}{l}\text { Latest } \\
\text { measurement }\end{array}$ & $\begin{array}{l}\text { Months after } \\
\text { transplantation }\end{array}$ \\
\hline $\begin{array}{l}1 \\
2 \\
3 \\
4\end{array}$ & $\begin{array}{l}86 \\
72 \\
55 \\
74\end{array}$ & $\begin{array}{l}76 \\
98 \\
65 \\
91\end{array}$ & $\begin{array}{r}27 \\
10 \\
15 \\
7\end{array}$ & $\begin{array}{r}102 \\
75 \\
71 \\
78\end{array}$ & $\begin{array}{r}93 \\
100 \\
78 \\
79\end{array}$ & $\begin{array}{r}27 \\
10 \\
15 \\
7\end{array}$ \\
\hline
\end{tabular}


Respiratory infection did not increase in spite of the need for immunosuppression. Formal pulmonary function tests in four children showed improved indices in three and only a slight decrease in patient 127 months after transplantation (table 3). Another unexpected benefit was a remission in diabetes in patient 4; she stopped taking insulin seven weeks after transplantation and was still in remission 14 months later.

\section{Discussion}

The liver disease of cystic fibrosis is thought to result primarily from the accumulation of abnormally tenacious bile in the intrahepatic ducts, which impedes bile flow and causes injury to the biliary epithelium and consequent biliary cirrhosis. In addition, there is increased faecal bile acid loss and this results in the production of hydrophobic bile acids which are potentially hepatotoxic. The improvement in liver function and nutrition status which has been observed when cystic fibrosis patients are treated with the hydrophilic bile salt ursodeoxycholic acid seems to support this hypothesis, ${ }^{45}$ but to date it is not known whether the progression of liver disease can be slowed by the early administration of this compound.

The characteristic early hepatic lesion is a focal biliary fibrosis with oedema, chronic inflammatory cell infiltration, bile duct proliferation, and increased fibrosis in portal tracts while the parenchyma contains relatively healthy hepatocytes. ${ }^{4}$ The principal consequence of the liver disease is the development of portal hypertension, which causes enlargement of the spleen and the formation of varices. Tests which reflect either hepatocyte function, such as protein synthesis, as indicated by the serum albumin and the prothrombin time, or cellular integrity, as indicated by the serum transaminase concentrations, may be normal or only slightly deranged.

The reported prevalence of clinically apparent liver disease among patients with cystic fibrosis is remarkably variable, ranging from $2 \cdot 2 \%$ to $24 \cdot 5 \%$. $^{236-8}$ In a review of 1100 patients Scott-Jupp et al found $4 \cdot 2 \%$ affected. ${ }^{2}$ The mean age at presentation was 9.8 years and in most the first sign to be detected was enlargement of the liver or spleen, or both. Although in that series only $7 \cdot 8 \%$ of the children died as a direct result of their liver disease, there was an increased mortality in teenagers with liver disease, probably due to exacerbation of the lung problems. Feigelson et al reported the long term outcome of 450 children with cystic fibrosis, among whom 31 $(7 \%)$ developed multilobular cirrhosis at a mean age of 7 years. $^{3}$ Twenty children had varices and seven had surgical treatment for their portal hypertension (five a portocaval shunt, one a splenectomy, and one triple transplantation). Six children died of liver complications after a mean survival of only 4.5 years, and 10 died from lung complications. Stern et al reported that, of five children who received portal systemic shunts for variceal bleeding, three were alive from one to nine years after the operation and two died at a mean of eight years. ${ }^{6}$ Others, such as Tyson et $a l,{ }^{9}$ have reported much poorer results, with six of 17 children dying within two months of the operation. Portal systemic shunting may be effective in relieving bleeding, but requires a major operation, may precipitate encephalopathy, and greatly complicates any subsequent attempt at liver transplantation.

There are few reports to date of the outcome of patients with cystic fibrosis after liver transplantation. Cox described five children and five adults who had only mild to moderate lung disease and received liver grafts; three patients died from infective complications, as a result of pseudomonas in two and aspergillus in one, but among the surviving patients pulmonary function improved in five. ${ }^{10}$ Mieles et al reported four children and five adults; two died from problems directly related to the operation but, among the seven patients who survived, pulmonary function either improved or remained stable. ${ }^{11}$ These two groups raised the question of whether colonisation of the lungs with pseudomonas increased the risk of death from pneumonia after transplantation and whether postoperative management should be modified. We have not seen an increase in postoperative morbidity from pulmonary infection after successful liver transplantation. Indeed, the most impressive outcome in this small series of children has been the improvement in subjective pulmonary symptoms. All the children had greatly improved exercise tolerance and decreased sputum production. There are several possible reasons for this unexpected benefit. Liver cirrhosis with portal hypertension causes abdominal distension and diaphragmatic splinting, which is relieved after transplantation; the liver disease is associated with intrapulmonary shunting and pulmonary oedema, which contributes to the lung problems; and malnutrition reduces resistance to infection. It is also possible that immunosuppressive treatment, perhaps particularly with cyclosporin, may exert a specific beneficial effect by blocking cytokine production and thereby inhibiting inflammatory processes in the airways. ${ }^{12}$

It was surprising that the diabetes of patient 4 showed a prolonged remission after liver transplantation as the cause of diabetes associated with cystic fibrosis seems primarily to be the mechanical disruption and destruction of pancreatic tissue rather than an autoimmune process. It has also been suggested that liver disease may unmask subclinical diabetes as the ability of a damaged liver to deal with a glucose load is impaired. ${ }^{13}$

In conclusion, we suggest that children with cystic fibrosis complicated by hepatic cirrhosis and portal hypertension, but with relatively well preserved lung function, should be considered for liver transplantation once varices are present. Such children are at constant risk from variceal bleeding and worsening of nutritional and respiratory status may lead to premature death from pulmonary complications. Liver transplantation remains a high 
risk procedure, but in cystic fibrosis, when successful, it is not attended with increased infective or pulmonary morbidity. Not only is the portal hypertension relieved and the danger of bleeding removed, but there may also be striking benefits in improved pulmonary function, nutrition, and in general wellbeing.

1 Elborn ST. Cystic fibrosis: prospects for gene therapy. Hospital Update 1994; 20: 13-20.

2 Scott-Jupp R, Lama M, Tanner MS. Prevalence of liver disease in cystic fibrosis. Arch Dis Child 1991; 66: 698-701.

3 Feigelson J, Anagnostopoulos C, Poquet M, Pecau Y, Munck A, Navarro J. Liver cirrhosis in cystic fibrosis therapeutic implications and long term follow up. Arch Dis Child 1993; 68: 653-7.

4 Tanner MS. Liver and biliary problems in cystic fibrosis. $f R$ Soc Med 1992; 85: 20-4.

5 Cotting J, Lentze MJ, Reichen J. Effects of ursodeoxycholic acid treatment on nutrition and liver function in patients with cystic fibrosis and longstanding cholestasis. Gut 1990; 31: $918-21$.

6 Stern RC, Stevens DP, Boat TF, Doershuk CF, Izant RJ,
Matthews LW. Symptomatic hepatic disease in cystic fibrosis: incidence, course, and outcome of portal systemic shunting. Gastroenterology 1976; 70: 645-9.

7 Nagel RA, Westaby D, Javaid A, et al. Liver disease and bile duct abnormalities in adults with cystic fibrosis. Lancet 1989; ii: 1422-5.

8 Schwarz HP, Kraemer R, Thurnheer U, Rossi E. Liver involvement in cystic fibrosis. Helv Paediatr Acta 1978; 33: 351-64.

9 Tyson KRT, Schuster SR, Schwachman H. Portal hypertension in cystic fibrosis. Pediatrics 1968; 3: 271-7.

$10 \mathrm{Cox}$ KL. The role of liver transplantation in cystic fibrosis patients. Cystic Fibrosis Conference 1990; S1.4: 78-9.

11 Mieles LA, Orenstein D, Teperman L, Podesta L, Koneru B, Starzl TE. Liver transplantation in cystic fibrosis. Lancet 1989; i: 1073

12 Greally P, Hussein MJ, Cook AJ, Sampson AP, Piper PJ, Price JF. Sputum tumor necrosis factor-alpha and leukotriene concentrations in cystic fibrosis. Arch Dis Child 1993; 68: 389-92.

13 Dodge JA, Morrison G. Diabetes mellitus in cystic fibrosis: a review. F $R$ Soc Med 1992; 85: 25-8.

14 Tanner JM, Whitehouse RH. Triceps and subscapular skinfolds standard charts. $B M \mathcal{F}$ 1962; i: $446-50$.

15 Frisancho AR. New norms of upper limb fat and muscle areas for assessment of nutritional status. Am f Clin Nutr 1981; 34: $2540-5$

\section{西 \\ 吕

\section{○}

